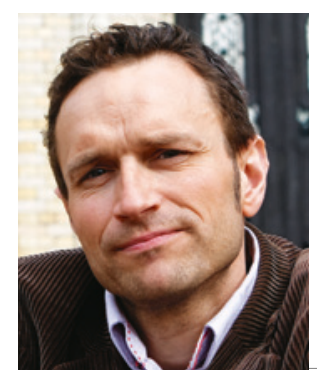

\title{
Betraktninger fra sykkelsetet
}

\author{
Hvordan vi forflytter oss og hva vi \\ spiser, har store konsekvenser for \\ helse, miljø og klima. Personlige \\ og politiske endringer som gir \\ helsegevinst, gir automatisk også \\ miljøgevinst. For å få med folk på \\ slike endringer, må det være prak- \\ tisk og lettvint.
}

Hver morgen setter jeg meg på en av menneskets fineste oppfinnelser, sykkelen, og triller fra Bøler ned til jobben i Oslo sentrum. En slik arbeidsreise kan virke sær midt på vinteren, når det er nødvendig med minst tre lykter, piggdekk, vintersykkelsko og ikke minst lag på lag med varme klær. For dem som ikke er vokst opp i Bergen, som jeg, kan det også virke aparte å sykle når regnet plasker i asfalten og du blir en skvettlapp for passerende biler. Men jeg har lært å kle meg. Vel, ikke alltid, i dag kom jeg klissvåt frem fordi himmelen åpnet seg noe overraskende over Galgeberg, kun få tråkk unna kontoret.

Helsegevinsten for oss som sykler, er enorm. Men havner vi ikke ofte på legevakten - og i verste fall ender vi ikke som kroppdelsdonorer? Statistisk sett er svaret nei. Helsefordelen ved å sykle er 20 ganger større enn risikoen for å forulykke, ifølge den britiske legeforeningen.

Helseargumentet er likevel ikke det viktigste for å få flere til å tråkke pedaler. Bare $19 \%$ av syklistene i København oppgir helse og mosjon som årsak til at de sykler, og kun $1 \%$ sykler av hensyn til miljøet. Syklisten tenker heller ikke økonomi. Bare $6 \%$ oppgir det som grunn. Det kan jeg kjenne meg igjen i. Med den slitasjen som er på sykkel og utstyr året gjennom, er ikke månedskort på t-banen et mye dyrere alternativ. Hva er så viktigst for tråkkende dansker? Godt over halvparten svarer: Det er lettvint og hurtig å sykle.

Det stemmer jo. For meg er det raskest å komme meg til jobben på tohjulingen. Dessuten er det moro. Det må ha noe med frihetsfølelsen å gjøre. Men, kanskje ikke overraskende, legger jeg mer vekt på miljøet enn københavnere flest. På sykkelen utgjør jeg ingen trussel mot klimaet, jeg bidrar mikroskopisk til svevestøvet og støyer knapt mer enn stokkandens padling i Østensjøvannet som jeg sykler langs.

København-undersøkelsen viser tydelig at miljø-eller helseargumenter ikke er nok for å få folk til å endre transportvaner. Det samme gjelder for våre matvaner. Det hjelper så godt som ingenting om myndighetene kjører kampanjer som sier at «du bør spise miljøvennlig mat». Det hjelper litt mer om de forteller oss hva som er skadelig eller bra for helsen.

Det finnes et helt ferskt eksempel på at bruk av både helse- og miljøargumenter fører frem. Regnskogfondet og Grønn hverdag klarte å få norske matbedrifter til å slutte å bruke palmeolje i sine produkter. Argumentene var at palmeoljefettet ikke er sunt for kroppen din, og verdifull regnskog, som orangutangen er avhengig av, hogges ned for å rydde plass til palmeoljeplantasjer.

Dette er bra! Men stat og kommune må gå lenger. Jeg vil bruke en enkel modell for å illustrere hvordan myndighetene kan fremme miljø og helse: Hva bør de slutte med, hva bør de begynne med og hva kan de fortsette med?
For å ta det første spørsmålet først: Slutt med å la reklamekontoret for kjøttindustrien, nemlig «Opplysningskontoret for kjøtt og egg», få lov til å dominere undervisningen i mat og helse på barneskolen. Både klimaforskere og helseforskere advarer mot det høye kjøttforbruket. Slutt med å gi nesten all landbruksstøtte til bønder som produserer kjøtt og animalske varer. Bønder som produserer vegetabilsk mat, må få en større andel. Få slutt på at arbeidsgivere tilbyr ansatte gratis bilparkering som skattefritt frynsegode. Sørg heller for at arbeidsgivere betaler for helsefremmende tiltak for ansatte, uten noen skattlegging.

Når det gjelder neste spørsmål, bør myndighetene begynne med å opprette et opplysningskontor for helse- og miljøvennlig mat, som gir rett kunnskap om matens økologiske påvirkning. Server lettvinte oppskrifter på vegetariske retter og bærekraftig sjømat. Prioriter syklister og gående høyere. Mal røde sykkelfelt i rundkjøringer i bystrøk og sørg for at andre trafikanter alltid respekterer syklister og gående. Sørg for at syklistene har egne sammenhengende veier. Sørg for brøyting om vinteren og feiing av grus lenge før 17. mai.

Da gjenstår det bare å antyde hva myndighetene bør fortsette med, det vil si når de ovennevnte forslagene er gjennomført: Fortsett å si at klimaendringene er vår tids største utfordring, og fortsett med å understreke at bedre folkehelse er det viktigste målet for helsepolitikken.

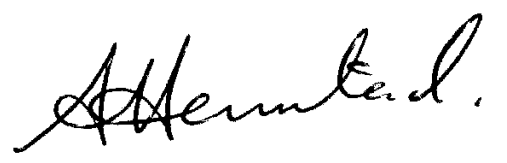

